\title{
Biweekly Cabazitaxel Is a Safe Treatment Option for Metastatic Castration-resistant Prostate Cancer (mCRPC) Patients After Docetaxel - A Final Analysis of the Prosty II Trial
}

\author{
PIRKKO-LIISA KELLOKUMPU-LEHTINEN ${ }^{1}$, TIMO MARTTILA $^{2}$, ANTTI JEKUNEN $^{3}$, PETTERI HERVONEN $^{4}$, \\ KATARIINA KLINTRUP ${ }^{5}$, VESA KATAJA ${ }^{6}$, TAPIO UTRIAINEN ${ }^{7}$, MARJAANA LUUKKAA $^{8}$, \\ MARKKU LESKINEN ${ }^{2}$, KALEVI PULKKANEN ${ }^{6}$, ANNA-LIISA KAUTIO $^{4}$ and TEPPO HUTTUNEN ${ }^{9}$ \\ ${ }^{1}$ Faculty of Medicine and Health Technology, University of Tampere and Center of Research, \\ Development and Innovation, Tays Cancer Center, Tampere University Hospital, Tampere, Finland; \\ ${ }^{2}$ Department of Urology, Seinäjoki Central Hospital, Seinäjoki, Finland; \\ ${ }^{3}$ Department of Oncology, Turku University, Vaasa Central Hospital, Vaasa, Finland; \\ ${ }^{4}$ Department of Oncology, Tampere University Hospital, Tampere, Finland; \\ ${ }^{5}$ Department of Oncology, Oulu University Hospital, Oulu, Finland; \\ ${ }^{6}$ Department of Oncology, Kuopio University Hospital, Kuopio, Finland; \\ ${ }^{7}$ Comprehensive Cancer Center, Helsinki University Central Hospital, Helsinki, Finland; \\ ${ }^{8}$ Department of Oncology and Radiotherapy, Turku University Hospital, Turku, Finland; \\ ${ }^{9} 4$ Pharma Ltd., Turku, Finland
}

\begin{abstract}
Background/Aim: Our phase III trial showed that biweekly docetaxel $(D)$ is better tolerated than triweekly $D$ in metastatic castration-resistant prostate cancer ( $m C R P C)$. The safety of biweekly cabazitaxel (CBZ) post-docetaxel was studied in $\mathrm{mCRPC}$. Patients and Methods: Altogether, 60 patients received $C B Z 16 \mathrm{mg} / \mathrm{m}^{2}$ i.v. on day 1 and day 14 of a 4-week cycle. The mean serum PSA levels were $305 \mathrm{ng} / \mathrm{ml}$, and the mean age 67 years. The primary endpoint was safety according to CTCAEv4.0. Results: A total of 255 4-week cycles of $C B Z$ were administered. The most common grade $3 / 4$ adverse events were neutropenia (16.7\%), pain (13.3\%), fatigue (10.0\%), anemia (5.0\%) and non-neutropenic infection (10.0\%). PSA responses occurred in 10 patients (16.7\%). Clinical benefit rate was $38.3 \%$ and median survival 10 months. Conclusion: Biweekly CBZ is a welltolerated treatment resulting in meaningful benefits for heavily pretreated $m C R P C$ patients.
\end{abstract}

This article is freely accessible online.

Correspondence to: Pirkko-Liisa Kellokumpu-Lehtinen, MD, Ph.D., Professor emerita, Faculty of Medicine and Health Technology, University of Tampere, BOX 2000, 33101 Tampere, Finland. Tel: +35 8505951103, e-mail: pirkko-liisa.kellokumpu-lehtinen@tuni.fi

Key Words: mCRPC, cabazitaxel, postdocetaxel, biweekly dosing.
Androgen deprivation is a standard noncurative treatment for advanced prostate cancer (APC). Although symptoms are reduced in approximately $70-80 \%$ of patients, APC invariably transforms into a castration-resistant disease after a median time of two to three years (1-3). Several treatment options have shown a survival benefit in patients with metastatic castration-resistant prostate cancer, including docetaxel plus prednisone (4) or docetaxel plus estramustine (5), cabazitaxel (CBZ) plus prednisone (6), abiraterone plus prednisone $(7,8)$, sipuleucel-T (9), enzalutamide, apalutamide, darolutamide $(3,10,11)$, and radium-223 (12). Aside from docetaxel and CBZ, other chemotherapy agents have only a modest activity against APC $(3,13-15)$.

The first two randomized trials, published in 2004, showed docetaxel to be superior to mitoxantrone plus prednisone, yielding a survival gain of approximately 2-3 months $(4,5)$. In both of these studies, the TAX-327 study and Southwest Oncology Group (SWOG) 9916 trial, docetaxel every three weeks alone or combined with estramustine was associated with more adverse events compared with mitoxantrone plus prednisone. These adverse events (AEs) included neutropenic fever, fatigue, diarrhea, nail changes, sensory neuropathy, and alopecia $(4,5)$. Based on these studies, docetaxel administered every three weeks intravenously in combination with oral prednisone has been considered standard first-line chemotherapy for metastatic castration-resistant prostate cancer (mCRPC). In addition, docetaxel in hormone-sensitive APC has been shown to 
increase survival by more than one year in large randomized trials $(16,17)$.

In our Prosty 1 trial, we showed that biweekly administration of docetaxel might be better tolerated than 3weekly docetaxel in elderly prostate cancer patients, and might lead to patients continuing treatment for longer. The biweekly dose of $50 \mathrm{mg} / \mathrm{m}^{2}$ docetaxel was both better tolerated and gave better progression-free and overall survival than the $75 \mathrm{mg} / \mathrm{m}^{2}$ dose every three weeks (18).

The phase III randomized TROPIC trial included 755 patients with mCRPC whose disease progressed during or after docetaxel-containing treatment (6). Patients were randomized to receive CBZ $25 \mathrm{mg} / \mathrm{m}^{2}$ every 3 weeks + prednisone/ prednisolone (CBZP) for 10 cycles $(n=378)$ or mitoxantrone 12 $\mathrm{mg} / \mathrm{m}^{2}$ every 3 weeks + prednisone/ prednisolone (MP) for 10 cycles $(n=377)$. Primary prophylaxis with granulocyte colony stimulating factor was not allowed at cycle 1 . The primary endpoint was overall survival; the secondary endpoints were progression-free survival, response rate and safety. The population in the TROPIC study was heavily pretreated: $60 \%$ had received radiotherapy, potentially decreasing the bone marrow reserve, and patients had received a median of 7 cycles of docetaxel prior to entry into the study. The median number of cycles delivered was 6 in the CBZP arm versus 4 in the MP arm. The median overall survival, 15.1 months, was longer in the CBZP arm compared to the MP arm, 12.7 months $(\mathrm{HR}=0.70,95 \% \mathrm{CI}=0.59-0.83, p<0.0001)$, and resulted in a $30 \%$ reduction in the risk of death. The progression-free survival was also longer in the CBZP arm, 2.8 months versus 1.4 months in the MP arm $(\mathrm{HR}=0.74,95 \% \mathrm{CI}=0.64-0.86, p<0.0001)$. AEs of grade $\geq 3$ occurred in $57.4 \%$ of patients in the CBZ group and $39.4 \%$ of patients in the mitoxantrone group, and serious AEs occurred in $39.1 \%$ and $20.8 \%$ of patients, respectively. The most frequently occurring grade $\geq 3$ AEs in the CBZ group were neutropenia $(81.7 \%$ at nadir), febrile neutropenia (7.5\%), diarrhea $(6.2 \%)$, fatigue $(4.9 \%)$, asthenia $(4.6 \%)$, back pain (3.8\%), leukopenia (3.8\%), and anemia (3.5\%). Eighteen deaths due to adverse events occurred during the trial in the CBZP arm vs. 7 in the MP arm, mainly due to neutropenic complications, often during cycle 1. Later, in the FIRSTANA trial, CBZ at two dose levels was compared with 3-weekly docetaxel as a firstline chemotherapy in mCRPC. The lower dose of CBZ was better tolerated, and both CBZP groups had similar survival as the group receiving docetaxel every three weeks (19).

The aim of this study was to explore a new, biweekly schedule of CBZ in metastatic castration-resistant prostate cancer patients after docetaxel treatment. Our hypothesis that a biweekly dosing regimen might be better tolerated than the every-three-weeks dosing regimen was based on our previous study, which showed that the biweekly administration of docetaxel as a $1^{\text {st }}$-line treatment of mCRPC was better tolerated than docetaxel administered every three weeks. Additionally, the efficacy of biweekly docetaxel was better than that of docetaxel every three weeks, and biweekly dosing presented a significant overall survival benefit (18). As the occurrence of neutropenia in the TROPIC trial was high, our aim was to reduce the incidence of severe adverse events by administrating a lower dose of CBZ more frequently, while maintaining the same dose intensity as in the every-three-weeks dosing schedule.

\section{Patients and Methods}

Patients. The enrolled patients were required to have histologically/ cytologically confirmed prostate cancer that had progressed during or after docetaxel treatment. Prior surgical castration or treatment with a luteinizing hormone-releasing hormone analog was mandatory for inclusion in the study. Other main inclusion criteria were World Health Organization (WHO) performance status 0 to 2; presence of distant metastases; and PSA $>10 \mathrm{ng} / \mathrm{ml}$ with a value that had increased in at least 2 consecutive measurements performed $\geq 2$ weeks apart. Exclusion criteria included a history of other cancer types and any medical condition that precluded the administration of chemotherapy. Patients with impaired liver function [serum bilirubin $>1.5 \times \mathrm{N}$ (times the normal upper limit), alanine or aspartate aminotransferase $>3.0 \times \mathrm{N}$, alkaline phosphatase $>5.0 \times \mathrm{N}$ except in the presence of bone disease and in the absence of liver disorder] were not eligible, nor were those who had impaired renal function (serum creatinine $>1.5 \times \mathrm{N}$ ), a blood neutrophil count $<1.5 \times 109 / \mathrm{ml}$, platelet count $<100 \times 10^{9} / \mathrm{ml}$, or hemoglobin $<110 \mathrm{~g} / \mathrm{l}$.

Primary and secondary endpoints. The primary endpoint was safety. Toxicity was graded according to the National Cancer Institute Common Terminology Criteria for Adverse Events, Version 4.0 (NCI CTC-AE v 4.0) (20). Secondary end points were time to treatment failure, response, survival and quality of life. The time to treatment failure was counted from the start of treatment to the end of treatment, including disease progression, adverse events, patient refusal or death.

Objective responses [complete response (CR) and partial response $(\mathrm{PR})]$ for measurable disease were assessed by investigators according to RECIST version 1.1 (21), while those for non-measurable disease were assessed by PCWG2. Confirmation of objective responses was performed by repeat tumor imaging [computed tomography (CT) scans, magnetic resonance imaging (MRI)] or evaluation of non-measurable disease at 6 weeks (at least 4 weeks for PSA) after the first documentation of response.

PSA response: A PSA decline of $\geq 50 \%$ was confirmed by a second PSA value at least four weeks later. The duration of the PSA response was measured from the first to the last assessment at which the above criteria were satisfied.

PSA progression: PSA progression was defined as an increase in PSA by $25 \%$ above the baseline level (at least $2 \mathrm{ng} / \mathrm{ml}$ ) in patients who had not achieved a $>50 \%$ decrease in PSA or an increase of $25 \%$ above the nadir value (at least $2 \mathrm{ng} / \mathrm{ml}$ ) in patients who had achieved a prior $>50 \%$ decrease in PSA. A confirmatory PSA was taken at least 3 weeks later. During the first twelve weeks of therapy, PSA rises were misleading. A rising PSA during the first 12 weeks of treatment, without clinical and/or radiological signs of progression, was not considered disease progression (22).

Overall survival was calculated from the start of treatment to death.

Quality of life assessment was performed using the Finnish translation of "Functional Assessment of Cancer Therapy-Prostate" 
Table I. Demographic characteristics.

WHO performance status; 0/1/2 (\%)

Baseline PSA (ng/ml); mean (SD)

Time from the diagnosis of prostate cancer (months); mean (SD)

Type of disease at diagnosis; Local/Metastatic (\%)
$18 / 40 / 2(30.0 / 66.7 / 3.3)$

$305.0(471.2)$

$84.7(61.7)$

$30 / 30(50.0 / 50.0)$
(FACT-P) questionnaire, version 4 (23). Pain was evaluated according to VAS (Visual Analog Scale).

Ethics. The study protocol was approved by the institutional review committees and was registered at ClinicalTrials.gov (identifier NCT01558219). All study participants provided written informed consent.

Medication. Jevtana ${ }^{\circledR}(\mathrm{CBZ}) 16 \mathrm{mg} / \mathrm{m}^{2}$ i.v. in $1 \mathrm{~h}$ on cycle day 1 was given every second week with prednisone/prednisolone $10 \mathrm{mg}$ PO daily. Intravenous premedication included antihistamine (dexchlorpheniramine $5 \mathrm{mg}$ or diphenhydramine $25 \mathrm{mg}$ or equivalent), corticosteroid (dexamethasone $8 \mathrm{mg}$ or equivalent), and $\mathrm{H} 2$ antagonist (ranitidine or equivalent) to be given $1 / 2$ hour prior to the treatment. Antiemetic prophylaxis (oral or intravenous) was recommended as needed.

Statistical analysis. The sample size was based on the following: a power of $80 \%$ is reached with 60 patients if testing against the $82 \%$ observed neutropenia in the TROPIC trial, using the assumption that $67 \%$ grade $3 / 4$ neutropenia will be observed with a new treatment regimen [i.e., a 15\% reduction from what was seen in the TROPIC trial by de Bono et al. (6)]. The primary interest in this study was safety. The incidence of grade $3 / 4$ neutropenia was the primary parameter. A 95\% confidence interval was calculated for the incidence and was tested against the historical control. With this sample size, the width of the $95 \%$ confidence interval is approximately $\pm 10 \%$. The incidence of other safety findings was also reported. The toxicity was graded according to the National Cancer Institute Common Terminology Criteria for Adverse Events, Version 4.0 (NCI CTC-AE v 4.0) and summarized using MedDRA terminology. Kaplan-Meier curve was used to analyse survival. A $p$-value less than 0.05 was considered significant.

\section{Results}

The baseline patient characteristics are shown in Table I. The mean age of the patients was 67 years (range $=50-79$ years). The time from prostate cancer diagnosis to the start of cabazitaxel treatment was 85 months, and the mean baseline PSA was $305 \mathrm{ng} / \mathrm{ml}$ (range $=3.7-2,425 \mathrm{ng} / \mathrm{ml}$ ).

A total of 253 cycles (one cycle was two biweekly doses) of cabazitaxel were administered. The median number of cycles was 4 . Nine patients $(15 \%)$ received less than 3 cycles, 19 patients $(32 \%)$ received at least 3 cycles, and 3 patients $(5 \%)$ received 12 cycles. No prophylactic G-CSF was used. All adverse events are summarized in Table II. The most common grade $3 / 4$ adverse events were neutropenia $10 / 60(16.7 \%)$, pain $8 / 60(13.3 \%)$, fatigue $6 / 60(10.0 \%)$, anemia 3/60 (5.0\%), non-neutropenic infection 6/10 (10.0\%), leucopenia $2 / 60(3.3 \%)$, neutropenic infection $1 / 60(1.7 \%)$, mucositis 1/60 (1.7\%), elevated ALP 1/60 (1.7\%) and limb edema $1 / 60(1.7 \%)$. In addition, one grade 4 pulmonary embolism and one intracerebral hemorrhage occurred. In one patient, a cancer-related bone fracture (grade $4 \mathrm{AE}$ ) occurred during the second CBZ cycle. During the treatment exposure period, reported AEs were as follows: grade 1 AEs in 3 pts (5.0\%), grade 2 AEs in 28 pts $(46.7 \%)$, grade 3 AEs in 24 pts $(40.0 \%)$ and grade 4 AEs in 5 pts $(8.3 \%)$.

Of the patients who were followed up, most (39 out of 60 , $65 \%$ ) discontinued the treatment due to progressive disease. Additional causes for stopping treatment were adverse events $(\mathrm{N}=17,28.3 \%)$ and other reasons $(\mathrm{N}=2.3 .3 \%)$, or death $(\mathrm{N}=1,1.7 \%)$. PSA responses occurred in 10 patients $(16.7 \%)$, and overall response as PR was recorded in 3 patients $(5.0 \%)$ and as stable disease (SD) in 20 patients $(33.3 \%$, leading to a clinical benefit ratio of $38.3 \%$ (Table III). The median overall survival was 10 months (Figure 1), and $33 \%$ of patients were alive at the end of the study.

The occurrence of grade 3/4 neutropenia was significantly lower than the predefined $82 \%$ at nadir in the TROPIC trial. The observed rate of grade $3 / 4$ neutropenia in our study was $16.7 \%$ (exact $95 \%$ confidence interval of $8.3 \%$ to $28.5 \%$, $p<0.0001$ compared to $82 \%$ rate) .

\section{Discussion}

At present, there is an appeal for physicians to treat elderly mCRPC patients with new androgen receptor (AR) pathwaytargeted agents, such as abiraterone acetate (AA) and enzalutamide, that have been proven to prolong overall survival (OS), and are orally delivered and well tolerated. However, because prostate cancer is a heterogeneous disease, all patients will not respond to AR-targeted agents (3). Indeed, some cancers present a primary resistance to these agents, and others will develop an acquired resistance over time. Moreover, retrospective studies involving a small number of patients suggest that once a patient's disease progresses after treatment with an AR-targeted agent, this patient will not respond to another AR-targeted agent. This assumption was shown to be true in a recent study of patients with postdocetaxel mCRPC treated with either abiraterone or enzalutamide $(6,10)$. In the randomized trial, patients treated with cabazitaxel had significantly longer survival than those 
Table II. Adverse events in all 60 patients treated with biweekly cabazitaxel.

\begin{tabular}{|c|c|c|c|c|c|}
\hline Grade & 0 & 1 & 2 & 3 & 4 \\
\hline Alopecia, n (\%) & $49(81.7)$ & $7(11.7)$ & $4(6.7)$ & 0 & 0 \\
\hline Diarrhea, n (\%) & 37 (61.7) & $16(26.7)$ & 7 (11.7) & 0 & 0 \\
\hline Fatigue, n (\%) & $14(23.3)$ & $22(36.7)$ & $18(30.0)$ & $5(8.3)$ & $1(1.7)$ \\
\hline Infection with nANC* & $49(81.7)$ & 0 & $5(8.3)$ & $6(10.0)$ & 0 \\
\hline Nail loss, n (\%) & $55(91.7)$ & $4(6.7)$ & $1(1.7)$ & 0 & 0 \\
\hline Nausea, n (\%) & $39(65.0)$ & $11(18.3)$ & $10(16.7)$ & 0 & 0 \\
\hline Vomiting, n (\%) & $48(80.0)$ & $10(16.7)$ & $2(3.3)$ & 0 & 0 \\
\hline Weight loss, n (\%) & $50(83.3)$ & $8(13.3)$ & $2(3.3)$ & 0 & 0 \\
\hline ALAT, n (\%) & $53(83.3)$ & $6(10.0)$ & $1(1.7)$ & 0 & 0 \\
\hline ASAT, n (\%) & $41(68.3)$ & $15(25.0)$ & $46.7)$ & 0 & 0 \\
\hline ALP, n (\%) & $30(50.0)$ & $22(36.7)$ & $6(10.0)$ & $2(3.3)$ & 0 \\
\hline Allergic reaction & $56(93.3)$ & $2(3,3)$ & $2(3.3)$ & 0 & 0 \\
\hline Anaphylaxis & $60(100)$ & 0 & 0 & 0 & 0 \\
\hline Bilirubin & $58(96.7)$ & $1(1.7)$ & $1(1.7)$ & 0 & 0 \\
\hline Creatinine & $32(53.3)$ & $24(40)$ & $4(6.7)$ & 0 & 0 \\
\hline Febr. neutropenia & $60(100)$ & 0 & 0 & 0 & 0 \\
\hline Fever & $53(88.3)$ & $6(10.0)$ & $1(1.7)$ & 0 & 0 \\
\hline Hemoglobin & $1(1.7)$ & $41(75.0)$ & $15(25.0)$ & $3(5.0)$ & 0 \\
\hline Neutropenic inf. & $57(95.0)$ & 0 & $2(3.3)$ & $1(1.7)$ & 0 \\
\hline Leukocytes & $42(70.0)$ & $6(10.0)$ & $10(16.7)$ & $2(3.3)$ & 0 \\
\hline Neutrophils & $39(65)$ & $4(6.7)$ & 7 (11.7) & $8(13.3)$ & $2(3.3)$ \\
\hline Platelets & $45(75.0)$ & $14(23.3)$ & $1(1.7)$ & 0 & 0 \\
\hline
\end{tabular}

nANC: Normal absolute neutrophil count; ALAT: alanine aminotrasferase; ASAT: asparate animotrasnferasel; ALP: alkaline phosphatase.

treated with either AR-targeted agent (24). Finally, the place of first-line androgen deprivation therapy (ADT) for advanced prostate cancer is now strongly challenged. The results of the CHAARTED trial showed that the addition of 6 cycles of docetaxel to ADT in patients with hormone-sensitive metastatic prostate cancer is associated with a survival benefit of more than one year versus ADT alone (17).

Older age is not an absolute contraindication to chemotherapy. Many elderly patients tolerate chemotherapy just as well as younger patients. Docetaxel-based regimens are the standard of care because they provide a survival advantage, while reducing pain and improving health-related quality of life (HR-QoL). In the TAX-327 trial, the survival benefit of 3-weekly docetaxel plus prednisone compared with mitoxantrone plus prednisone was consistent among age groups (25). In men aged 75 years and older, the 3-weekly schedule resulted in more dose reductions than the weekly schedule $(22 \%$ versus $8 \%, p=0.007)$, but tolerability was otherwise comparable (25). In a prospective survey involving 333 mCRPC patients at least 70 years old, a taxane-based regimen was associated with significantly improved OS, progression-free survival (PFS), and clinical benefit (based on pain and analgesic consumption) than a non-taxane regimen, even in frail patients $(26,27)$.

Cabazitaxel is a new taxane developed to overcome docetaxel resistance and to penetrate the blood-brain barrier
Table III. Final response evaluation

\begin{tabular}{lc}
\hline PSA response & \\
\hline PR & $10(16.7 \%)$ \\
SD & $22(36.7 \%)$ \\
PD & $18(30.0 \%)$ \\
NA & $10(16.7 \%)$ \\
\hline Target and non-target lesion evaluation & \\
\hline CR & - \\
PR & $3(5.0 \%)$ \\
SD & $20(33.3 \%)$ \\
PD & $32(53.3 \%)$ \\
NA & $5(8.3 \%)$
\end{tabular}

CR: Complete response; PR: partial response; SD: stable disease; PD: progressive disease.

(28). In nonresistant tumors, cabazitaxel shows a similar activity as docetaxel. In 168 patients in the phase 3 FIRSTANA trial, CBZ failed to demonstrate superiority in OS when compared to docetaxel $75 \mathrm{mg} / \mathrm{m}^{2}$ as first-line treatment in metastatic prostate cancer, possibly because patients were docetaxel naïve and less than $1 \%$ had received prior abiraterone or enzalutamide (19). CBZ and docetaxel had different toxicity profiles: docetaxel was associated with 


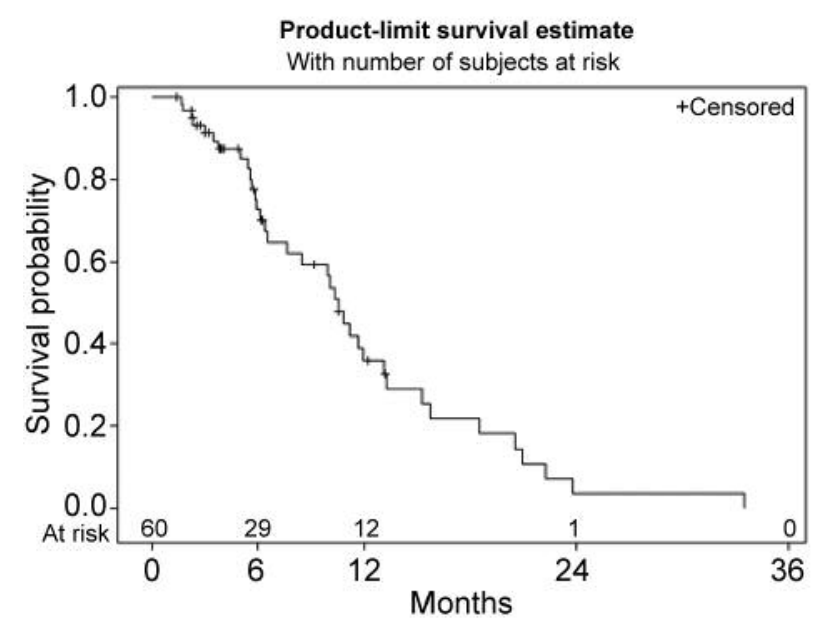

Figure 1. Kaplan-Meier curve of the survival of all patients.

more peripheral neuropathy, peripheral edema, alopecia, and nail disorders (19). In the TROPIC trial, cabazitaxel plus prednisone significantly prolonged OS versus mitoxantrone plus prednisone in mCRPC patients progressing during or after docetaxel therapy (5). It has also been shown that cabazitaxel retains its antitumor activity in patients progressing on AA or enzalutamide, with a higher efficacy than docetaxel (27). However, cabazitaxel is associated with a high incidence of grade $\geq 3$ neutropenia, although a large European compassionate-use program has clearly shown that this hematological toxicity was manageable even in patients 75 years and older $(26,29)$. Prophylactic management of adverse events, including an increased use of granulocytecolony stimulating factor (G-CSF), could significantly improve the risk of febrile neutropenia and/or neutropenic complications in elderly patients $(26,27,30)$.

It was shown in our Prosty 1 trial, a phase III trial involving 344 patients, that a biweekly administration of docetaxel plus prednisone for mCRPC is better tolerated than a three-weekly administration (18). Therefore, the efficacy of 2-weekly docetaxel was better than that of 3-weekly docetaxel with a longer time to progression (TTP) and a significant OS benefit.

The purpose of the present study was to evaluate whether the safety profile of cabazitaxel may further be improved with biweekly administration. Patients with MCRPC who were previously treated with docetaxel received cabazitaxel $16 \mathrm{mg} / \mathrm{m}^{2}$ every 2 weeks until disease progression or unacceptable toxicity. G-CSF was not given systematically. Our results showed that biweekly dosing was much better tolerated than the 3-weekly dosing regime in the TROPIC trial (6) and PROSELICA trial (31). In both studies, G-CSF was not allowed during cycle 1 , and neutropenia was determined by hematology tests performed at nadir (Days 8 and 15). Even with the lower cabazitaxel dose of $20 \mathrm{mg} / \mathrm{m}^{2}$ in PROSELICA, $42 \%$ of patients experienced grade 3 or greater neutropenia. In addition, in the FIRSTANA trial, with the lower $20 \mathrm{mg} / \mathrm{m}^{2}$ dose, the grade 3 or 4 treatmentemergent $\mathrm{AE}$ rate was $46.0 \%$. In this Prosty II trial, only $16.7 \%$ of patients had grade 3 or greater neutropenia, and $65 \%$ of patients did not have any neutropenia during the biweekly dosing of cabazitaxel. Thus, the primary endpoint of our trial was achieved. In addition, the survival of these heavily pretreated patients with advanced disease was quite long in our trial, and in the same range as in the FIRSTANA and PROSELICA trials. According to our results, biweekly cabazitaxel is a safe and well-tolerated option even after docetaxel for mCRPC.

\section{Conflicts of Interest}

Antti Jekunen, Katariina Klintrup, Vesa Kataja, Tapio Utriainen, Kalevi Pulkkanen, Anna-Liisa Kautio and Teppo Huttunen: no conflicts of interest. Pirkko-Liisa Kellokumpu-Lehtinen: Travel expenses from Sanofi, hornoraria for lecturing from BMS. Timo Marttila: Travel expenses from Sanofi, honoraria for lecturing from Jansen and Astellas. Markku J. Leskinen: Travel expenses from Sanofi and Astellas, honoraria for lecturing from Amgen, honoraria for expert testimony from Ipsen. Marjaana Luukkaa: Scientific congress costs from Astellas, Merck and Sanofi, honoraria for lecturing from BMS.

\section{Authors' Contributions}

Conception and design: Pirkko-Liisa Kellokumpu-Lehtinen, Timo Marttila, Marjaana Luukkaa, Petteri Hervonen, Anna-Liisa Kautio, Tapio Utriainen, Vesa Kataja. Administrative support: Pirkko-Liisa Kellokumpu-Lehtinen. Provision of study materials or patients: Pirkko-Liisa Kellokumpu-Lehtinen, Timo Marttila, Antti Jekunen, Petteri Hervonen, Katariina Klintrup, Vesa Kataja, Tapio Utriainen, Marjaana Luukkaa, Markku Leskinen, Kalevi Pulkkanen, Anna-Liisa Kautio. Collection and assembly of data: All Authors. Data analysis, interpretation and final approval of manuscript: Pirkko-Liisa Kellokumpu-Lehtinen and Teppo Huttunen drafted the first manuscript and all Authors approved the final manuscript. Financial and funding support: Sanofi and the Competitive State Research Financing of the Expert Responsibility area of Tampere University Hospital.

\section{References}

1 Damber JE and Aus G: Prostate cancer. Lancet 371: 1710-1721, 2008. PMID: 18486743. DOI: 10.1016/S0140-6736(08)60729-1

2 Seruga B and Tannock IF: Chemotherapy-based treatment for castration-resistant prostate cancer. J Clin Oncol 29: 3686-3694, 2011. PMID: 21844499. DOI: 10.1200/JCO.2010.34.3996

3 Gillessen S, Attard G, Beer TM, Beltran H, Bossi A, Bristow R, Carver B, Castellano D, Ha Chung B, Clarke N, Daugaard G, Davis ID, de Bono J, Borges dos reis R, Drake CG, Eeles R, Estathiou E, Evans CP, Fanti S, Feng F, Fizazi K, Frydenberg M, Gleave M, Halabi S, Heidenreich A, Higano CS, James N, 
Kantoff P, Kellokumpu-Lehtinen P-L, Khauli RB, Kramer G, logothetis C, Maluf F, Morgans AK, Morris MJ, Mottet N, Murthy WO, PoH W, Ost P, Padhani AR, Parker C, Pritchard CC, Roach M, Rubin M, Ryan C, Saad F, Sartor O, Scher H, Sella A, Shore N, Smith M, Soulu H, Sternberg CN, Suzuki H, Sweeney C, Sydes MR, Tannock I, Tombal B, Valdagni R, Wiegel T and Omlin A: Management of patients with advanced prostate cancer: The report of advanced prostate cancer consensus conference APCCC2017. Eur Urol 73: 178-211, 2018. PMID: 28655541. DOI: 10.1016/j.eururo.2017.06.002

4 Tannock IF, de Wit, Berry WR, Horti J, Pluzanska A, Chi KN, Oudard S, Théodore C, James ND, Turesson I, Rosenthal MA, Eisenberger MA and TAX 327 Investigators: Docetaxel plus prednisone or mitoxantrone plus prednisone for advanced prostate cancer. N Engl J Med 351: 1502-1512, 2004. PMID: 15470213. DOI: $10.1056 /$ NEJMoa040720

5 Pertylak DP, Tangen CM, Hussain MH, Lara PN Jr, Jones JA, Taplin ME, Burch PA, Berry D, Moinpour C, Kohli M, Benson MC, Small EJ, Raghavan D and Crawford ED: Docetaxel and estramustine compared with mitoxantrone and prednisone for advanced refractory prostate cancer. N Engl J Med 351: 15131520, 2004. PMID: 15470214. DOI: 10.1056/NEJMoa041318

6 De Bono JS, Oudard S, Ozguroglu M, Hansen S, Machiels JP, Kocak I, Gravis G, Bodrogi I, Mackenzie MJ, Shen L, Roessner M, Gupta S, Sartor AO and TROPIC Investigators: Prednisone plus cabazitaxel or mitoxantrone for metastatic castration resistant prostate cancer progressing after docetaxel treatment: a randomised open-label trial. Lancet 376: 1147-1154, 2020. PMID: 20888992. DOI: 10.1016/S0140-6736(10)61389-X

7 de Bono JS, Logothesis CJ, Molina A, Fizazi K, North S, Chu L, Chi KN, Jones RJ, Goodman OB Jr, Saad F, Staffurth JN, Mainwaring P, Harland S, Flaig TW, Hutson TE, Cheng T, Patterson H, Hainsworth JD, Ryan CJ, Sternberg CN, Ellard SL, Fléchon A, Saleh M, Scholz M, Efstathiou E, Zivi A, Bianchini D, Loriot Y, Chieffo N, Kheoh T, Haqq CM, Scher HI and COUAA-301 Investigators: Abiraterone and increased survival in metastatic prostate cancer. N Engl J Med 364: 1955-2005, 2011. PMID: 21612468. DOI: 10.1056/NEJMoa1014618

8 Ryan CJ, Smith MR, de Bono JS, Molina A, Logothetis CJ, de Souza P, Fizazi K, Mainwaring P, Piulats JM, Ng S, Carles J, Mulders PF, Basch E, Small EJ, Saad F, Schrijvers D, Van Poppel H, Mukherjee SD, Suttmann H, Gerritsen WR, Flaig TW, George DJ, Yu EY, Efstathiou E, Pantuck A, Winquist E, Higano CS, Taplin ME, Park Y, Kheoh T, Griffin T, Scher HI and Rathkopf DE; COU-AA-302 Investigators: Abiraterone in metastatic prostate cancer without previous chemotherapy. N Engl J Med 368: 138148, 2013. PMID: 23228172. DOI: 10.1056/NEJMoa1209096

9 Kantoff PW, Higano CS, Shore ND, Berger ER, Small EJ, Penson DF, Redfern CH, Ferrari AC, Dreicer R, Sims RB, Xu Y, Frohlich MW and Schellhammer PF; IMPACT Study Investigators: Sipuleucil -T immutherapy for casration-resistant prostate cancer. N Engl J Med 363: 411-422, 2010. PMID: 20818862. DOI: 10.1056/NEJMoa1001294

10 Scher HI, Fizazi K, Saad F, Taplin ME, Sternberg CN, Miller K, de Wit R, Mulders P, Chi KN, Shore ND, Armstrong AJ, Flaig TW, Fléchon A, Mainwaring P, Fleming M, Hainsworth JD, Hirmand M, Selby B, Seely L, de Bono JS and AFFIRM Investigators: Increased survival with enzalutamide in prostate cancer after chemotherapy. N Engl J Med 367: 1187-1197, 2012. PMID: 22894553. DOI: 10.1056/NEJMoa1207506
11 Beer TM, Armstrong AJ, Rathkopf DE, Loriot Y, Sternberg CN, Higano CS, Iversen P, Bhattacharya S, Carles J, Chowdhury S, Davis ID, de Bono JS, Evans CP, Fizazi K, Joshua AM, Kim CS, Kimura G, Mainwaring P, Mansbach H, Miller K, Noonberg SB, Perabo F, Phung D, Saad F, Scher HI, Taplin ME, Venner PM, Tombal B and PREVAIL Investigators: Enzalutamide in metastatic prostate cancer before chemotherapy. N Engl J Med 371: 424-331, 2014. PMID: 24881730. DOI: 10.1056/NEJMoa1405095

12 Sartor O, Coleman R, Nilsson S, Heinrich D, Helle SI, O'Sullivan JM, Fosså SD, Chodacki A, Wiechno P, Logue J, Widmark A, Johannessen DC, Hoskin P, James ND, Solberg A, Syndikus I, Vogelzang NJ, O'Bryan-Tear CG, Shan M, Bruland $\varnothing S$ and Parker C: Effect of radium-223 dichloride on symptomatic skeletal events in patients with castration-resistant prostate cancer and bone metastases: results from a phase 3, double-blind, randomised trial. Lancet Oncol 15: 738-746, 2014. PMID: 24836273. DOI: 10.1016/S1470-2045(14)70183-4

13 Berthold DR, Pond GR, Soban F, de Wit R, Eisenberger M and Tannock IF: Docetaxel plus prednisone or mitoxantrone plus prednisone for advanced prostate cancer: updated survival in the TAX 327 study. J Clin Oncol 26: 242-2455, 2008. PMID: 18182665. DOI: $10.1200 / \mathrm{JCO} .2007 .12 .4008$

14 Fitzpatrick JM, Bellmunt J, Fizazi K, Heidenreich A, Sternberg C N, Tombal B, Alcaraz A, Bahl A, Bracarda S, Di Lorenzo G, Efstathiou E, Finn SP, Fosså S, Gillessen S, KellokumpuLehtinen PL, Lecouvet F Oudard S, de Reijke T, Robson C, Santis M, Seruga B and de Wit R: Optimal management of metastatic castration-resistant prostate cancer: highlights from a European Expert Consensus Panel. Eur J Cancer 50: 1617-1627, 2014. PMID: 24703899. DOI: 10.1016/j.ejca.2014.03.010

15 National Comprehensive Cancer Network. Clinical practice guidelines in oncology. Prostate cancer. Available at: http://www.nccn.org/professionals/physician_gls/f_guidelines.as p [Last accessed February 27, 2020]

16 James ND, Sydes MR, Clarke NW, Mason MD, Dearnaley DP, Ritchie AWS, Amos CL, Gilson C, Jones RJ, Matheson D, Millman R, Attard G, Chowdhury S, Cross WR, Gillessen S, Parker CC, Russell JM, Berthold DR, Brawley C, Adab F, Aung S, Birtle AJ, Bowen J, Brock S, Chakraborti P, Ferguson C, Gale J, Gray E, Hingorani M, Hoskin PJ, Lester JF, Malik ZI, McKinna F, McPhail N, Money-Kyrle J, O'Sullivan J, Parikh O, Protheroe A, Robinson A, Srihari NN, Thomas C, Wagstaff J, Wylie J, Zarkar A, Parmar MKB, Sydes MR and STAMPEDE Investigators: Addition of docetaxel, zoledronic acid, or both to first-line longterm hormone therapy in prostate cancer (STAMPEDE): Survival results from an adaptive, multiarm, multistage, platform randomised controlled trial. Lancet 387: 1163-1177, 2016. PMID: 28578639. DOI: 10.1056/NEJMoa1702900

17 Sweeney CJ, Chen YH, Carducci M, Jarrard DF, Eisenberger M, Wong YN, Hahn N, Kohli M, Cooney MM, Dreicer R, Vogelzang NJ, Picus J, Shevrin D, Hussain M, Garcia JA and DiPaola RS: Chemohormonal therapy in metastatic hormonesensitive prostate cancer. N Engl J Med 373: 737-746, 2015. PMID: 28159490. DOI: 10.1016/j.urolonc.2016.12.021

18 Kellokumpu-Lehtinen PL, Harmenberg U, Joensuu T, McDermott R, Hervonen P, Ginman C, Luukkaa M, Nyandoto P, Hemminki A, Nilsson S, McCaffrey J, Asola R, Turpeenniemi-Hujanen T, Laestadius F, Tasmuth T, Sandberg K, Keane M, Lehtinen I, Luukkaala T, Joensuu H and PROSTY study group: 2-Weekly versus 3-weekly docetaxel to treat castration-resistant advanced prostate 
cancer: a randomised, phase 3 trial. Lancet Oncol 14: 117-124, 2013. PMID: 23294853. DOI: 10.1016/S1470-2045(12)70537-5

19 Oudard S, Fizazi K, Sengeløv L, Daugaard G, Saad F, Hansen S, Hjalm-Eriksson M, Jassem J, Thiery-Vuillemin A, Caffo O, Castellano D, Mainwaring PN, Bernard J, Shen L, Chadjaa M and Sartor O: Cabazitaxel versus docetaxel as first-line therapy for patients with metastatic castration-resistant prostate cancer: A randomized phase III trial - FIRSTANA. J Clin Oncol 35: 31893197, 2017. PMID: 28753384. DOI: 10.1200/JCO.2016.72.1068

20 Common Terminology Criteria for Adverse Events (CTCAE) v.4.03. June 14, 2010. Available at: http://evs.nci.nih.gov/ftp1/ CTCAE/About.htm [Last accessed November 14, 2020]

21 Eisenhauer Therasse P, Bogaerts J, Schwartz LH, Sargent D, Ford R, Dancey J, Arbuck S, Gwyther S, Mooney M, Rubinstein L, Shankar L, Dodd L, Kaplan R, Lacombe D and Verweij J: New response evaluation criteria in solid tumours: revised RECIST guideline (version 1.1). Eur J Cancer 45: 228-247, 2009. PMID: 19097774. DOI: 10.1016/j.ejca.2008.10.026

22 Bubley GJ, Carducci M, Dahut W, Dawson N, Daliani D, Eisenberger M, Figg WD, Freidlin B, Halabi S, Hudes G, Hussain M, Kaplan R, Myers C, Oh W, Petrylak DP, Reed E, Roth B, Sartor O, Scher H, Simons J, Sinibaldi V, Small EJ, SmithMR , Trump DL and Wilding G: Eligibility and response guidelines for phase II clinical trials in androgen-independent prostate cancer: Recommendations from the PSA Working group. J Clin Oncol 17: 3461-3467, 1999. PMID: 10550143. DOI: $10.1200 / J C O .1999 .17 .11 .3461$

23 Cella DF1, Tulsky DS, Gray G, Sarafian B, Linn E, Bonomi A, Silberman M, Yellen SB, Winicour P and Brannon J: The functional assessment of cancer therapy (FACT) scale: development and validation of the general measure. J Clin Oncol 11: 570-579, 1993. PMID: 8445433. DOI: 10.1200/JCO.1993.11.3.570

24 de Wit R, de Bono J, Sternberg CN, Fizazi K, Tombal B, Wülfing C, Kramer G, Eymard JC, Bamias A, Carles J, Iacovelli R, Melichar B, Sverrisdóttir Á, Theodore C, Feyerabend S, Helissey C, Ozatilgan A, Geffriaud-Ricouard C, Castellano D and CARD Investigators: Cabazitaxel versus abiraterone or enzalutamide in metastatic prostate cancer. N Engl J Med 381: 2506-2518, 2019. PMID: 31566937. DOI: 10.1056/NEJMoa1911206

25 Horgan AM, Seruga B, Pond GR, Alibhai SM, Amir E, De Wit R, Eisenberger MA and Tannock IF: Tolerability and efficacy of docetaxel in older men with metastatic castrate-resistant prostate cancer (mCRPC) in the TAX 327 trial. J Geriatr Oncol 5: 119126, 2015. PMID: 24495703. DOI: 10.1016/j.jgo.2013.12.001
26 Heidenreich A, Bracarda S, Mason M, Ozen H, Sengelov L, Van Oort I, Papandreou C, Fossa S, Hitier S and Angel Climent M and European investigators: Safety of cabazitaxel in senior adults with metastatic castration-resistant prostate cancer: results of the European compassionate-use programme. Eur J Cancer 50: 10901099, 2014. PMID: 24485664. DOI: 10.1016/j.ejca.2014.01.006

27 Droz JP, Albrand G, Gillessen S, Hughes S, Mottet N, Oudard S, Payne H, Puts M, Zulian G, Balducci L and Aapro M: Management of prostate cancer in elderly patients: Recommendations of a Task Force of the International Society of Geriatric Oncology. Eur Urol 72: 521-531, 2017. PMID: 28089304. DOI: 10.1016/j.eururo. 2016.12.025

28 Vrignaud P, Semiond D, Benning V, Beys E, Bouchard H and Gupta S: Drug design, development and therapy. Drugs Dec Dev Ther 8 : 1851-1867, 2014. PMID: 25378905. DOI: 10.2147/DDDT.S64940

29 Zhang $\mathrm{T}$ and Armstrong $\mathrm{AI}$ : The who, what, and how. Cabazitaxel treatment in metastatic castration-resistant prostate cancer. J Clin Oncol 35: 3175-3177, 2017. PMID: 28809609. DOI: $10.1200 / J C O .2017 .74 .7931$

30 Droz JP, Aapro M, Balducci L, Boyle H, Van den Broeck T, Cathcart P, Dickinson L, Efstathiou E, Emberton M, Fitzpatrick JM, Heidenreich A, Hughes S, Joniau S, Kattan M, Nicolas Mottet N, Oudard S, Payne H, Saad F and Sugihara T: Management of prostate cancer in older patients: updated recommendations of a working group of the International Society of Geriatric Oncology. Lancet Oncol 15: e404-e414, 2014. PMID: 25079103. DOI: 10.1016/S1470-2045(14)70018-X

31 Eisenberger M, Hardy-Bessard AC, Kim CS, G'eczi L, Ford D, Mourey L, Carles J, Parente P, Font A, Kacso G, Chadjaa M, Zhang W, Bernard J and Bono J: Phase III study comparing a reduced dose of cabazitaxel $\left(20 \mathrm{mg} / \mathrm{m}^{2}\right)$ and the currently approved dose $\left(25 \mathrm{mg} / \mathrm{m}^{2}\right)$ in postdocetaxel patients with metastatic castration-resistant prostate cancer - PROSELICA. J Clin Oncol 35: 3198-3206, 2017. PMID: 28809610. DOI: 10.1200/JCO.2016.72.1076
Received October 27, 2020

Revised November 14, 2020

Accepted November 17, 2020 